\title{
Statyba
}

\section{CHLORIDE PENETRATION INTO MORTAR FOR NON- DESTRUCTIVE DETERMINATION OF THE CHLORIDE BINDING ISOTHERM}

\section{J.-P. Bigas}

To cite this article: J.-P. Bigas (1999) CHLORIDE PENETRATION INTO MORTAR FOR NONDESTRUCTIVE DETERMINATION OF THE CHLORIDE BINDING ISOTHERM, Statyba, 5:1, 28-31, DOI: $10.1080 / 13921525.1999 .10531429$

To link to this article: https://doi.org/10.1080/13921525.1999.10531429

Published online: 26 Jul 2012.

Submit your article to this journal $\llbracket$

Џ Article views: 49 


\title{
CHLORIDE PENETRATION INTO MORTAR FOR NON-DESTRUCTIVE DETERMI- NATION OF THE CHLORIDE BINDING ISOTHERM
}

\author{
J.-P. Bigas
}

\section{Introduction}

To evaluate the service life concrete structure exposed to marine environment, it will be important to predict the penetration of chloride ions into concrete. The Fick's second law gives the chloride concentration $\mathrm{C}$ as a function of the distance $\mathrm{x}$ from the exposed surface and as a function of the time $t$, assuming a constant $\mathrm{D}$, intrinsic chloride diffusion coefficient in a semi-infinite porous medium:

$$
\frac{\partial C}{\partial t}=D \frac{\partial^{2} C}{\partial x^{2}} .
$$

Equation (1) is valid only if there is no interaction between chloride and solid phases. In fact, when binding process (chemical and physical) occurs, the chloride penetration is slower. Then, the determination of $\mathrm{D}$ should be reduced to:

1. the measurement of the effective diffusion coefficient $D_{e}$,

2. the quantification of the binding process.

The differential equation describing the migration of chloride into concrete [1] should be written as:

$$
\frac{\partial C}{\partial t}=D_{a} \frac{\partial^{2} C}{\partial x^{2}}
$$

with $D_{a}=\frac{D \tau}{\alpha}=\frac{D_{e}}{\alpha}$ defined as the apparent diffusion coefficient, taking into account the binding phenomenon between the liquid phase and the solid phase [2, 3]. The capacity factor $\alpha$ is expressed as $\alpha=\tau+(1-\tau) \rho_{s} K_{d}$. Assuming an instantaneous exchange driven by a linear binding isotherm $K_{d}$ is the binding capacity as $C s=K_{d} C$ with $C s$ as bound chloride, $\tau$ as concrete porosity and $\rho_{s}$ its density.
In fact, the apparent diffusion coefficient $D_{a}$ which takes into account chloride binding, is not a constant because the binding isotherm is non-linear. Classical determinations [4] of binding isotherm are done on crushed materials, neglecting the real microstructure of the concrete, particularly the microcracks. Our original approach $[6,7]$, which takes into account the bulk microstructure of the material, is based on an utilisation of the data obtained with classical diffusion tests.

\section{Materials and methods}

These tests were realised on mortars samples (Table 1). The 28 day characteristics for the mortar cured in water at $20^{\circ} \mathrm{C}$ are: compressive strength $=$ $40 \mathrm{MPa}$, density $\rho_{s}=2400 \mathrm{~kg} / \mathrm{m}^{3}$, water porosity $\tau_{\text {water }}=0.16$ and mercury porosity $\tau=0.14$.

Table 1. Mix proportions

\begin{tabular}{l|l}
\hline \multicolumn{1}{c|}{ Materials } & \\
\hline CPA-CEM I & $519 \mathrm{~kg} / \mathrm{m}^{3}$ \\
\hline Siliceous sand $(0.6 / 1.2 \mathrm{~mm})$ & $1067 \mathrm{~kg} / \mathrm{m}^{3}$ \\
Siliceous sand $(1.2 / 25 \mathrm{~mm})$ & $457 \mathrm{~kg} / \mathrm{m}^{3}$ \\
Water & $255 \mathrm{Vm}$ \\
\hline
\end{tabular}

After curing, slices were removed from $11 * 22 \mathrm{~cm}$ cylinders and placed in diffusion cells. The diffusion area is $7.088 .10^{-3} \mathrm{~m}^{2}$, and the volume of both compartment of this cells is $3.73 .10^{-4} \mathrm{~m}^{3}$. Each cell was filled with an alcaline solution of $\mathrm{KOH}(4.65 \mathrm{~g} / \mathrm{l})$ and $\mathrm{NaOH}(1 \mathrm{~g} / \mathrm{l})$ at $\mathrm{pH} 13$.

Different concentration gradients (Table 2) are obtained using different initial concentration $C_{o}$ in chloride and using different thickness of slices. 
Table 2. Experimental program. The $X$ sign indicates the tested variables

\begin{tabular}{l|c|c|c|c|c}
\hline & $\begin{array}{c}C_{O}= \\
169.6 \mathrm{~g} / \mathrm{l}\end{array}$ & $\begin{array}{c}C_{\sigma}= \\
20.2 \mathrm{~g} / 1\end{array}$ & $\begin{array}{c}C_{o}= \\
10.0 \mathrm{~g} / 1\end{array}$ & $\begin{array}{c}C_{\theta}= \\
5.0 \mathrm{~g} / 1\end{array}$ & $\begin{array}{c}C_{\sigma}= \\
1.0 \mathrm{~g} / \mathrm{l}\end{array}$ \\
\hline $\mathrm{L}=1 \mathrm{~cm}$ & $\mathrm{X}$ & $\mathrm{X}$ & $\mathrm{X}$ & $\mathrm{X}$ & $\mathrm{X}$ \\
$\mathrm{L}=1.5 \mathrm{~cm}$ & & $\mathrm{X}$ & $\mathrm{X}$ & & \\
\hline
\end{tabular}

The downstream solution was removed at regular term (twice a month) to maintain the $C=0$ condition at $x=L$. At each term the chloride content was determined by a potentiometric method.

\section{Modelling}

For linear binding, the resolution of Fick's second law, shows an asymptotic increase of the quantities of diffused chloride with time when steady state occurs (Fig 1). The time lag $t_{i}$, is defined as the abscissa of the asymtote [1]:

$$
t_{i}=\frac{\alpha L^{2}}{6 D_{e}}
$$

$D_{e}$, is assumed to be independent of $C_{0}$, and calculated from the slope of the asymptote.

Without binding, the factor capacity $\alpha$ is represented by the porosity, the time lag is:

$$
t_{i}=\frac{\tau L^{2}}{6 D_{e}}=\frac{L^{2}}{6 D} \text {. }
$$

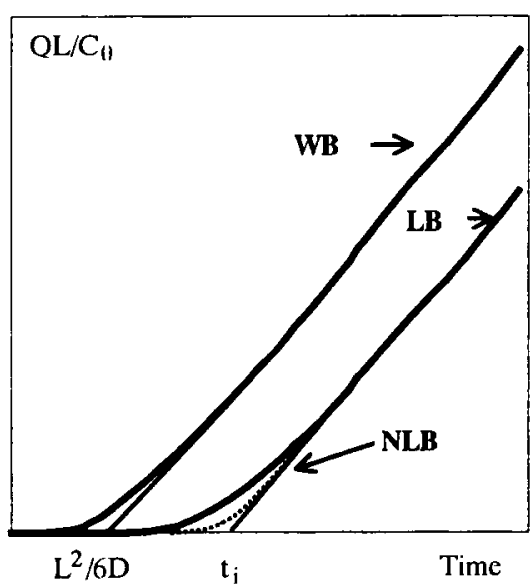

Fig 1. Diffusion curves; WB diffusion without binding, LB diffusion with linear binding, NLB diffusion with non-linear binding
The steady state regime, characterised by a linear concentration profile in the liquide phase between the upstream and the downstream cells, is independent of the non-linearity or the linearity of the isotherm. In the case of non-linear binding, we can write:

$$
\frac{Q L}{C_{0}}=D_{e} t-\alpha_{e q} \frac{L^{2}}{6}
$$

where $\alpha_{e q}$ is the equivalent capacity factor of the diffusion with linear binding which have the same asymptotic flow as the diffusion with non-linear binding. The abscissa of the intercept of the asymptote is:

$$
t_{i}=\frac{\alpha_{e q} L^{2}}{6 D_{e}}=\frac{L^{2}}{6 D}+\frac{L^{2}}{6 D_{e}}(1-\tau) \rho_{s} K_{d e q},
$$

where $K_{d e q}$ is the equivalent binding capacity of the equivalent linear isotherm.

\section{Definition of an equivalent linear isotherm and of an equivalent capacity factor}

Let us assume that the non-linear binding is described by a Freundlich isotherm $C s=a C^{y}$ with $0 \leq y \leq 1$. The basis of our modelling is to make the non-linear Freundlich binding isotherm similar to an equivalent linear isotherm.

The equivalent linear isotherm, associated to $\alpha_{e q}$, is defined as the one, which gives at $C_{o} / 2$, the same bound chloride concentration as the non-linear isotherm (Fig 2).

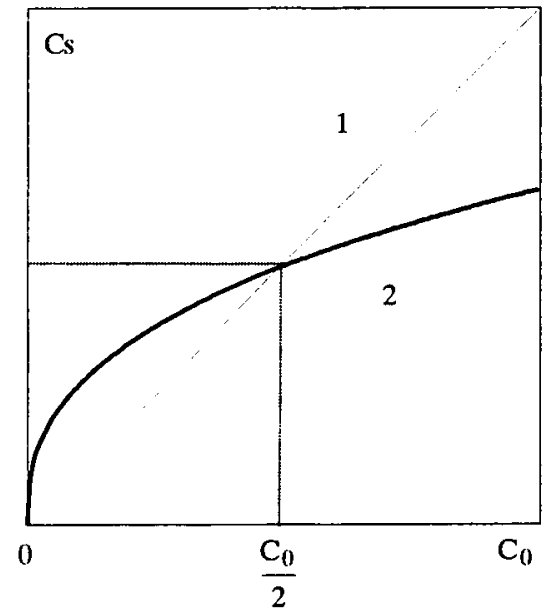

Fig 2. Chloride binding isotherms: Curve 1 is the linear equivalent isotherm and curve 2 is the Freundlich isotherm 


\section{Experimental results}

For each diffusion test drived for a given concentration or a given thickness, we obtain the data for $t_{i}, D_{e}$ and $\alpha_{e q}$ (Table 3) by a graphic determination from the diffusion curves.

Table 3. Experimental data for $t_{i}, D_{e}$, et $\alpha_{e q}$

\begin{tabular}{ccccc}
\hline$C_{o}(\mathrm{~g} / \mathrm{l})$ & $\mathrm{L}$ & $t_{i} ;(\mathrm{d})$ & $\begin{array}{c}D_{e} \exp \\
\left(10^{-12} \mathrm{~m}^{2} / \mathrm{s}\right)\end{array}$ & $\alpha_{e q} \exp$ \\
\hline 169.6 & 1 & 35 & 1.15 & 0.210 \\
20.2 & 1 & 64 & 1.93 & 0.639 \\
20.2 & 1.4 & 131 & 2.04 & 0.706 \\
10.0 & 1 & 86 & 2.43 & 1.081 \\
10.0 & 1.44 & 175 & 2.45 & 1.075 \\
5.0 & 0.95 & 112 & 2.63 & 1.690 \\
1.0 & 0.96 & 200 & 2.93 & 3.290 \\
\hline
\end{tabular}

On the basis of these experimental results, we make a numerical simulation [7] resolving the Fick's second law in the case of binding drived by an equivalent linear isotherm (in this case $y=1$ ). Then we obtain the corrected values of $D_{e}$ and $\alpha_{e q}$. Also the decrease in the concentration in the upstream cells can be calculated for a given term (Table 4).

Table 4. Adjusted data obtained by numerical simulation with the equivalent linear isotherm

\begin{tabular}{cccccc}
\hline$C_{o}$ & $\mathrm{~L}$ & $D_{e}$ & $\alpha_{e q}$ & $K_{\text {deq }}$ & $\frac{C_{01}-\Delta C_{0}}{C_{0}}$ \\
$(\mathrm{~g} / \mathrm{l})$ & $\left(10^{-2} \mathrm{~m}\right)$ & $\left(10^{-12} \mathrm{~m}^{2} / \mathrm{s}\right)$ & & $\left(10^{-3} \mathrm{~m}^{3} / \mathrm{kg}\right)$ & \\
\hline 169.6 & 1 & 1.18 & 0.215 & 0.037 & 0.949 \\
20.2 & 1 & 2.04 & 0.676 & 0.26 & 0.897 \\
20.2 & 1.4 & 2.19 & 0.763 & 0.30 & 0.859 \\
10.0 & 1 & 2.75 & 1.226 & 0.53 & 0.799 \\
10.0 & 1.44 & 2.77 & 1.212 & 0.51 & 0.792 \\
5.0 & 0.95 & 3.07 & 1.985 & 0.89 & 0.753 \\
1.0 & 0.96 & 3.62 & 4.072 & 1.95 & 0.633 \\
\hline
\end{tabular}

Two main observations should be made; firstly, the effective diffusion coefficient is a function of the chloride concentration and secondly the equivalent capacity factor is a function of the chloride concentration.

\section{Determination of the Freundlich isotherm para- meters}

The definition of the equivalent linear isotherm specify that the retention rates are the same for $C_{0} / 2$ considering linear or Freundlich isotherm.

So we can write:

$$
\begin{aligned}
& K_{d e g}\left(\frac{C_{0}}{2}\right)=\alpha\left(\frac{C_{0}}{2}\right)^{y} \text {, then } K_{\text {deg }}=\alpha\left(\frac{C_{0}}{2}\right)^{y-1} \text { and } \\
& \alpha_{e q}=\tau+(1-\tau) \rho_{s} \alpha\left(\frac{C_{0}}{2}\right)^{y-1} .
\end{aligned}
$$

Based on experiments, each diffusion test give us several couples of data $\left(C_{0} ; \alpha_{e q}\right)$ and from the equation (7) the equivalent capacity factor $\alpha_{e q}$ can be consider as a linear function of $\left(\frac{C_{0}}{2}\right)^{y-1}$. A linear regression procedure is then carried out to determine the Freundlich parameters " $y$ " and " $a$ ". In this procedure $y$ is considered as a parameter varying from 0 to 1 .

Experimentals data of $\alpha_{e q}$ are plotted (Fig 3) in function of $\left(\frac{C_{0}}{2}\right)^{y-1}$ and for each values of $y$, we determine the regression straight line and the standard deviation.

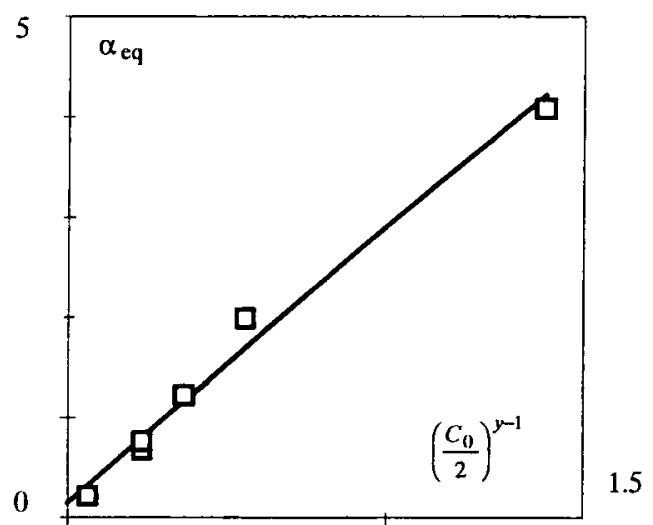

Fig 3. $\alpha_{e q} \nu s\left(\frac{C_{0}}{2}\right)^{y-1}$ for $y=0.38$

The value of $y$ chosen is the one which gives us the minimum standard deviation (Fig 4) associated to a realistic value of the porosity.

Next it is possible to determine the porosity $\tau$ and the coefficient " $a$ " of the Freundlich equation calcula- 
ted from the slope $\left[(1-\tau) \rho_{s} a\right]$ of the regression straight line.

From our experimental studies, we obtain a minimum standard deviation and a porosity value of 0.14 for $y=0.38$.

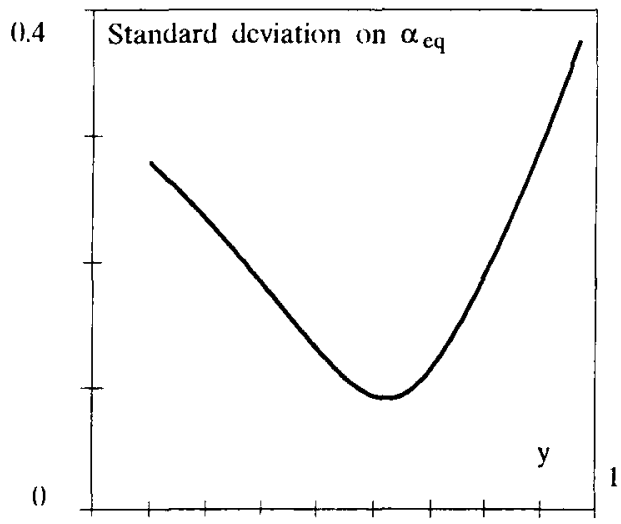

Fig 4. Standard deviation on $\alpha_{e q} v s y$

The straight line equation is:

$$
\alpha_{e q}=0.149+2.73\left(\frac{C_{o}}{2}\right)^{-0.62} \text {, }
$$

so we get $a=1 \cdot 34 \cdot 10^{-3}$.

For our mortar, the non-linear binding isotherm expressed as a Freundlich isotherm is:

$$
C s=1.34 .10^{-3} C^{0.38} \text {. }
$$

\section{Conclusion}

Seven classical chloride diffusion tests on mortar made with CPA-CEM I 42.5 cement have shown the dependence between the chloride concentration $C_{0}$ and the quantity of chloride bound by the solid phase. The non-linearity of chloride binding for the bulk material could be expressed by a Freundlich isotherm. A method based on equivalent linear isotherms has been presented.

\section{References}

1. J. Cranck. The Mathematics of diffusion. 2nd edition Clarendon Oxford, 1975.

2. M. Massat, L. O. Nilsson, J. P. Olliver. A clarification of the fundamental relationships concerning ion diffusion in porous materials. 3rd MRS Colloquium, 1992.

3. A. Atkinson. A. K. Nickerson. The diffusion of ions through water-saturated cement // Journal of Materials Science, 18, 1984, p. 3068-3078.

4. L. Tang. L. O. Nillson. Chloride binding capacity and binding isotherms of OPC pastes and mortars // Cement and Concrete Research 23, 1993, p. 247-253.

5. J. P. Bigas. La diffusion des ions chlore dans les mortiers. PhD thesis. Toulouse. Frence, 1994.

6. J. P. Bigas, F. Lambert, J. P. Ollivier. Modélisation globale des interactions physico-chimiques régies par des isothermes non linéaires entre ions chlore et mortier de ciment Portland // Materials and Structures, 29, 1996, p. 277-285.

7. F. Lambert. PhD thesis. USTL Montpellier. France, 1997.

Iteikta 19980623

CHLORIDO SKVARBA I SKIEDIKLI KAIP NEARDOMASIS BŪDAS CHLORIDO RIŠAMAJAI IZOTERMAI NUSTATYTI

\section{J. P. Bigas}

\section{S antrauka}

Chlorido issiskverbimo ił betono struktūrą koeficientą galima būtų nustatyti išmatavus efektyviosios difuzijos koeficienta, nustačius nelinijini chlorido ir betono rišimąsi. Siūlomas naujas būdas rišimosi procesui modeliuoti Freundlicho izoterma, apskaičiavus jos lygti iš keliu tradicinių difuzijos bandymų pastoviosios būkles sąlygomis.

Siūlomo būdo pranašumas (palyginti su klasikiniais bandymu metodais, kai rišimosi izotermos gaunamos is trupintų bandinių) yra tas, kad taikoma nelinijinio rišimosi izotermos lygtis betono mikrostruktūrai natūraliomis eksploatacijos sąlygomis. Šiuo atveju galima studijuoti mikrostruktūros poveiki chlorido jony risimuisi.

Jean-Philippe BIGAS. Doctor of INSA de Toulouse (1994), Maître Conférences. Institut Universitaire de Technologie Dpt Génie Civil. Laboratoire Matériaux et Sciences des Constructions. Université de Cergy Pontoise, rue d'Eragny, 95031 Cergy-Pontoise, France. Research interests: durability of concrete, fine admixture in high strength concrete. 